\title{
Towards transforming a system
}

\section{Re-thinking incarceration for youth (and beyond)}

\section{Lisa Marqua-Harries, Grant Stewart and Venessa Padayachee*}

lisamarqua@hotmail.com

grant.stewart@r-cubed.co

venessa@nicro.co.za

http://dx.doi.org/10.17159/2413-3108/2019/i68a5632

Rethinking crime and punishment, especially with regard to youth, ${ }^{1}$ is a priority for South Africa; a country with high crime rates, recidivism and an overburdened criminal justice system. The present punitive and retributive system often only exacerbates many underlying causes of crime and violence, especially in young people. The failure of the existing system suggests that the time is right for a paradigm shift in society's response to crime and punishment. A challenge to implementing any alternative justice model is to ensure that it does not continue to prop up the under-resourced, overburdened and dysfunctional criminal justice system it seeks to reform. The current systemic crisis demands radical reform, not merely adopting a few well-meaning tweaks to a broken system. This article argues that the system and its various forms (including residential options but with an emphasis on community-owned interventions) need to be both trauma-informed and infused with an ethos of restorative justice. We articulate our explanations with youth as the focus and make proposals in light of this and suggest a path towards implementation.

South Africa, in common with most other nations, uses imprisonment as the norm for the execution of serious criminal justice sanctions. ${ }^{2}$ In addition, remand detention is used excessively and for long periods without justification. ${ }^{3}$ South Africa's criminal justice system has undergone reforms aimed at

\footnotetext{
Lisa Marqua-Harries is Director of the NGO Restore and has her MA in Restorative Justice with the University of Hull, UK. Grant Stewart is a youth development and trauma-informed process facilitator and trainer with Restore Reconnect Rebuild (Pty) Ltd. Venessa Padayachee is the national advocacy and lobbying manager at NICRO. She has a degree in Social Work and a MA in Criminology.
}

reflecting the tenets of the Constitution and undoing the legacy of our oppressive past. The direction of these institutional changes, therefore, has placed greater emphasis on human rights and included a more restorative vocabulary in policy documents. ${ }^{4}$ The Department of Correctional Services (DCS) states that its mission is to contribute 'to a just, peaceful and safer South Africa through effective and humane incarceration of inmates, rehabilitation and social reintegration of offenders. ${ }^{5}$ However, with prisons continually struggling with the recurring issues of 
overcrowding and accompanying violence, these ideals have not been met. ${ }^{6}$ This should not be surprising: it is a global problem.

What follows is relevant to all age cohorts, however, the focus here is on youth due to their vulnerability and the significance of developmental needs.

\section{An incarceration legacy}

Incarceration, for many, is synonymous with criminal justice, even though it is a relatively recent phenomenon as penal policy. ${ }^{7}$ Prior to incarceration, corporal and capital punishment were the practiced norm, ${ }^{8}$ with prisons predominantly used for those awaiting trial, the execution of sentences or housing of debtors, vagabonds and others that were considered as social undesirables. ${ }^{9}$

Without delving into the complex evolution of incarceration, it is worth noting that the generally accepted purpose of imprisonment is to deprive the individual, who has transgressed, of their liberty and thereby achieve the goals of retribution, incapacitation, deterrence and rehabilitation. ${ }^{10}$ Purpose, though, is best determined by practice rather than by stated intention. Thus, prisons in fact function primarily as a tool for maintaining the socioeconomic stratifications in a society, with the overwhelming majority of those incarcerated being the poor and oppressed. ${ }^{11}$ Another way of stating this is that prisons serve the role of 'hiding' the poor, providing cheap labour and preserving the racial hierarchy. ${ }^{12}$ We can see this in South Africa's past, where housing compounds for African migrant labourers provided a blueprint for many of the prisons still in operation today. ${ }^{13}$

It is well known that the apartheid justice system was a repressive tool in the hands of the state and that incarceration made little, if any, distinction between activists, criminals, children and adults. ${ }^{14}$ Since 1994 there have been moves to reform the criminal justice system away from the apartheid legacy. Guided by a constitutional demand for safe, secure and humane incarceration, prisons were demilitarised (although, it is interesting to note, that a military-like staff uniform was retained) and corporal punishment banned. ${ }^{15}$ Restorative justice vocabulary and practice has also become part of the discourse with, for example, this model being officially adopted by the national government's Justice Crime Prevention and Security Cluster as a policy objective to be included in criminal justice, civil law, family law and African traditional justice. ${ }^{16}$ The White Paper on Corrections ${ }^{17}$ and the Child Justice Act 2008 (Act 75 of 2008) perhaps best defines this shift. Grounded in restorative justice, these policy documents aimed to fundamentally change the way in which children in conflict with the law were to be treated. ${ }^{18}$

There is a gap, though, between intentions, policies and practice. Despite the encouraging changes, incarceration has remained the de facto penalty for crime and, in addition, has not been sufficiently reformed, remaining largely unchanged within an increasingly punitive criminal justice system. ${ }^{19}$ This is evident in recurring issues of, inter alia, rights violations, corruption, lawlessness, overcrowding, violence and a lack of access to services. ${ }^{20}$ The Child Justice Act has provided notable changes and successes, however, it has not been sufficiently resourced and has faced challenges in implementation. ${ }^{21}$ Poor or misunderstood application of the law has meant that the police may be arresting fewer children; ${ }^{22}$ diversion programmes and secure care facilities often do not distinguish between the different needs of youth; ${ }^{23}$ and secure care facilities for young offenders face issues of rights violations, violence and poor conditions and operate as incarceration in all but name. ${ }^{24}$ 


\section{A different way of thinking}

Regardless of location or how they are labelled, prisons do not work. They have a tendency towards abuse - a feature that may even be inherent to the system. ${ }^{25}$ Walgrave, for example, argues that '[r]elying on punishment for dealing with crime leads to more imprisonment, more human and financial costs, weaker ethics and less public safety. ${ }^{26}$ And when we consider the suffering experienced by many in marginalised and oppressed communities, prison is often an extension of community experience, including a space for gang organisation and networking. ${ }^{27}$ Reguillo describes that '[w]hen death, instability, uncertainty, hopelessness and detachment become rooted as everyday experiences, punishment by example is irrelevant.'28

And yet, despite the evidence of their ineffectiveness, the use of prisons is expanding across the globe. ${ }^{29}$ If we hope to remedy the problems with the system, mere programmatic or policy change will not suffice. What is needed is a different way of thinking about crime and punishment - a more ambitious vision that not only changes prisons but transforms the criminal justice system as a whole and which challenges its role in reinforcing poverty, inequality and violence. Interventions require a broader understanding of the origins of crime and violence and must provide programming that is spiritual, psychological as well as social in nature. ${ }^{30}$ To make these changes would be no small feat: we only need to look at how long it took to pass the Child Justice Act for proof. ${ }^{31}$ We acknowledge the complexity of the sometimes divergent goals of safety for citizens, the pursuit of justice and social development. We argue, however, that it starts by ensuring that the system itself becomes trauma-informed and restorative justice infused, with an emphasis on youth.

\section{Trauma-informed and restorative justice-infused}

\section{Trauma-informed}

Using the word 'trauma' can be controversial as doing so too often assumes that the problem lies within the individual rather than the environment in which the individual lives. ${ }^{32}$ Behaviour, even criminal behaviour, can be viewed in a different way if one takes into consideration the real and ongoing external threats experienced by many people, coupled with their historical oppression. ${ }^{33}$ In these environments, aggression, callousness and hyper/hypo arousal can be understood as a natural and adaptive survival response in threatening environments, rather than as symptomatic of a disorder. ${ }^{34}$ Furthermore, using a 'disease' approach can obscure the agency ${ }^{35}$ in individuals' actions in the face of oppression, exclusion and marginalisation. ${ }^{36}$ For the purposes of this article and to incorporate these dynamics we define trauma as 'the subjective experience of loss, threat, powerlessness and exclusion that results in a negative change in how we view ourselves, our relationship to others and our place in the world. ${ }^{37}$

Research has shown that people in South Africa, especially those from socio-economically marginalised communities, have been exposed to multiple forms of violence across multiple settings over extended periods. ${ }^{38}$ This has massive implications for human development: the field of neuroscience has recently highlighted the profound impact that these lived realities can have on the brain. ${ }^{39}$ The problems and challenges that result manifest across the different domains of society, including the criminal justice arena. ${ }^{40}$ These problems often are related to a dysregulated or sensitised state of threat that manifest in, among other things, impulsive and/or aggressive behaviour as well as in learning challenges. ${ }^{41}$ Numerous studies have demonstrated that these challenges are present 
in the majority of youth involved in the criminal justice system. ${ }^{42}$

When we include the practices and discourses of racial and economic exclusion and racial profiling we see how these situational factors play a significant role in why many young people come into conflict with the law. ${ }^{43}$ Punitive practices and threatening environments are therefore often ineffective, especially since prison is another threatening space. ${ }^{44}$ More often incarceration will result in worse behaviour. ${ }^{45}$ It is crucial, then, that we develop a justice framework that factors in the lived realities of violence and exclusion of many who enter the system. ${ }^{46}$

\section{Restorative justice}

Restorative justice is a natural fit with a traumainformed approach. While there is no universally accepted definition of restorative justice, often leading to confusion and even misuse, ${ }^{47} \mathrm{a}$ simple definition that draws on several elements of the paradigm is that it is 'a theory of justice that emphasises repairing the harm caused or revealed by criminal behaviour. It is best accomplished through inclusive and cooperative processes. ${ }^{48}$ There is far more agreement on the values and principles that makes restorative justice distinguishable from other approaches to crime and punishment, including that: ${ }^{49}$

- crime is fundamentally a violation of people and interpersonal relationships;

- violations create obligations and liabilities; and

- restorative justice seeks to heal and put right the wrongs. ${ }^{50}$

The goals of restorative justice are also pertinent. These include putting key decisions in the hands of those most affected by crime and violence; making justice more healing and ideally more transformative; and reducing the likelihood of future offences. ${ }^{51}$ Restorative justice offers a more participative, reconciliatory, healing and problem-solving approach to crime and punishment than the current overly-punitive criminal justice system. The punitive approach is founded on a faulty belief that incarceration, with degradation, humiliation and dehumanisation will transform the offender into a more honest or docile person upon release. ${ }^{52}$ Instead, we argue, it only adds to the disconnection and brokenness of society.

Restorative justice should not merely be seen as an alternative to punishment but should instead be adopted as a foundation upon which justice is administered. It should not be an ad hoc programme to be implemented at any specific stage in the criminal justice process, but should rather be an underlying philosophy and guiding practice. Unless restorative justice is grounded in a set of clearly articulated values and principles, there is real danger that its potential can be subverted by the conventional justice system. ${ }^{53}$ Furthermore, we argue that this model is not limited to criminal justice, but can be applied in various settings such as schools, using a variety of restorative processes and interventions.

In light of the above, we recommend that the South African criminal justice system be re-conceptualised such that its foundation is trauma-informed and restorative justice-infused. Over the long term that would mean that all players along the criminal justice spectrum, from police to prosecutors, judges to correctional officials, act in ways that are grounded in this philosophy. The system can then still be tough on crime, but do so through a practice that is more restorative in the way that it deals with those who offend and their communities. We believe that community-based processes should be the primary focus of the criminal justice system in South Africa, with institutional care being kept as the option of last resort.

To work towards a more appropriate criminal justice system model for youth we suggest the 
following guiding principles for

its development: ${ }^{54}$

- A system-wide understanding of trauma and restorative practices. This means the broader justice system integrates this understanding into policy, practice and implementation at relevant institutions. ${ }^{55}$

- Safety. This is a constitutional imperative. In addition, from a neuroscience perspective we know that individuals who feel safe are less likely to overreact and more able to engage with new skills and behaviour. ${ }^{56}$ We should therefore be seeking to expand safe spaces within the wider criminal justice system beyond children's courts and sexual offences courts. We should develop strategies to ensure that the police and law enforcement can become trusted actors in communities.

- Supportive and respectful relationships. Punitive approaches do not work, especially with youth. ${ }^{57}$ Therefore, at an organisational and institutional level we should ensure that trauma-informed strategies and restorative practices inform the responses of adults and/or those in authority. ${ }^{58}$ Perry et al. suggest that "[p]romoting relational health by increasing the quality, number and density of supportive, nurturing and trauma-informed people is the most effective and enduring form of intervention. ${ }^{59}$

- Self-regulation. Encouraging self-regulation is a major task, particularly with those individuals who are more aggressive and impulsive. The ability to be aware and respond appropriately when a situation is escalating, requires engagement with higher brain functioning to enable a change in thinking processes and learn new skills. ${ }^{60}$ It also includes the ability to resist actions that will compromise future goals - in other words, developing a sense of purpose. This requires not just teaching but modelling regulation.
- Strength-based behaviour. This is not just about eliminating negative behaviour but building up areas of strength and developing aspects such as problemsolving skills; viewing people as assets and not liabilities; and providing encouragement and positive feedback.

\section{Empowering communities as frontline responders}

The empowerment of communities is key to successful implementation of our proposed model. Communities must be empowered with the capacity to act as frontline responders to transgressions and conflicts that take place within their own community. This could mean working with community leaders, elders and/ or those with 'street cred' to enable them to be effective mediators in conflict and for community building. This could take the form of restorative circles, restorative conferences, diversion and victim-offender dialogues. Marginalised communities in South Africa have a history of policing themselves and thus the energy and desire is already present. ${ }^{61}$ We agree with Community Connections for Youth that '[t]he community is central not peripheral...too often the communities in which young people reside, and will ultimately return, are engaged only as an afterthought...'62

A prime example of success in this regard is that of the Zwelethemba model or Community Peace Programme, started in Worcester, that aimed to practice civil policing and conflict resolution outside of the criminal justice system. ${ }^{63}$ This community model has been widely cited but it was shelved due to lack of resources (or rather, we argue, a lack of political will).

\section{Institutional care where necessary}

Without being naïve, we also need to acknowledge that there will still be those people who pose a threat to society, as well as to 
themselves. A need for residential care therefore remains, even though for youth under18 it should always be a last resort (as per the Child Justice Act). ${ }^{64}$ Residential care institutions, especially for youth, must also be designed according to trauma-informed restorative justice principles and values. An example is the monastic model for violent youth proposed by Garbarino, since it 'emphasizes contemplation, reflection, service, cooperation, meditation and peace, instead of confrontation, dominance and power assertion.' ${ }^{65}$ These principles must also be incorporated into the architectural design, colour, light and composition of spaces. ${ }^{66}$ The architect and designer Deanna Van Buren posits that ' $[\mathrm{t}$ ]he built environment forms the containers for nearly all the activities of our lives. These containers have a profound impact on how we feel and behave...values are inherent in its materials, forms and layout. ${ }^{\prime 67}$ In saying this we therefore acknowledge that a redesign of the physical spaces of prisons and the Child and Youth Care facilities is needed.

\section{Conclusion}

As far as we are aware, trauma-informed restorative-oriented options are not currently in practice in South Africa, even though legislation such as the Child Justice Act 2008 has brought a much-needed emphasis on a restorative approach along with an awareness of the impact of context. Making the shift to a more restorative system will require the willingness to accept the inherent failings of a systemic legacy inherited from our past and enable us to see that being 'tough on crime' does not require punitive and violent measures.

The integration of trauma-informed and restorative justice principles and values can help lead the way in re-conceptualising the South African criminal justice system. It must form the foundation and basis of thinking in every decision in the system, from policing, to arrest, through to the courts and the decisions made from there. The chequered history of prison reform in South Africa suggests that changes that are viewed as merely just another reform, will be compromised in their efficacy because of the deep and seemingly intractable problems in the system. Furthermore, the violent nature of imprisonment only exacerbates the trauma of young, and adult, offenders. The criminal justice system can no longer continue doing what it is doing and expect a different result.

We therefore propose a way forward that is based on strengthening community-owned interventions, as well as constructing more transformational structures, especially for youth, where it is necessary. We believe that by using a framework that is trauma-informed and based on restorative justice principles we can rebuild a criminal justice system that can more effectively reduce the levels of crime and violence. Adopting this approach could facilitate opportunities for young offenders to heal and develop healthy ways of being and relating in the world.

\section{To comment on this article visit \\ http://www.issafrica.org/sacq.php}

\section{Notes}

1 This article uses the UN definition of youth, which is persons between the ages of 15 and 24 years; see www.unesco.org/ new/en/social-and-human-sciences/themes/youth/youthdefinition/ (accessed 24 September 2018).

2 AK Akih and $Y$ Dreyer, Penal reform in Africa: The case of prison chaplaincy, HTS Teologiese Studies/Theological Studies, 73:3, 2017, http://dx.doi.org/10.4102/hts. v73i3.4525.

3 C Ballard, Research report on remand detention in South Africa: An overview of the current law and proposals for reform, Bellville: Community Law Centre, 2011.

4 D van Zyl Smit, Criminological ideas and the South African transition, in K McEvoy and T Newburn (eds), Criminology, conflict resolution and restorative justice, Basingstoke and New York, Palgrave MacMillan, 2003.

5 Department of Correctional Services, About us: mission/ vision/values, www.dcs.gov.za/?page_id=174 (accessed 11 September 2018).

6 LM Muntingh, An analytical study of South African prison reform after 1994, unpublished PhD thesis, University of the Western Cape, Cape Town, 2012, iii.

7 DH Drake, Prisons, punishment and the pursuit of security, Critical Criminological Perspectives Series, Basingstoke: Palgrave Macmillan, 2012; SB Singh, Doing time for crime: the 
historical development of the different models (approaches) of treatment for incarcerated offenders at the Westville Correctional Centre, Durban, South Africa, New Contree, 70 , Special Edition, 2014, http://hdl.handle.net/10394/12859.

8 Ibid.

9 A Coyle, The prisons we deserve, London: Harper Collins Publishers, 1994.

10 Drake, Prisons, punishment and the pursuit of security.

11 M Alexander, The new Jim Crow: Mass incarceration in the age of colorblindness, New York: The New Press, 2012; L Wacquant, Punishing the poor: The neoliberal government of social insecurity, Durham: Duke University Press, 2009; HA Thomson, The prison-industrial complex: A growth industry in a shrinking economy, New Labour Forum, 21:3, 2012, https://doi.org/10.4179/NLF.213.0000006.

12 Alexander, The new Jim Crow; Thomson, The prisonindustrial complex

13 Singh, Doing time for crime.

14 A Singh and $V$ Singh, A review of legislation pertaining to children, with particular emphasis on programmes offered to children awaiting trial at secure care centres in South Africa, Social Work/Maatskaplike Werk, 50:1, 2014, http://dx.doi. org/10.15270/50-1-18.

15 Muntingh, An analytical study of South African prison reform after 1994; S Oppler, Correcting Corrections: Prospects for South Africa's Prison, ISS Monograph 29, 1998, www. issafrica.org/publications/monographs (accessed 4 September 2015).

16 Justice, Crime Prevention and Security (JCPS) Cluster, Draft Media Briefing, 13 December 2015, www.justice.gov.za/m_ statements/2015/20151213-JCPSClusterMediaBriefingState ment.pdf (accessed 10 September 2018).

17 Department of Corrections, White Paper on Corrections in South Africa, Pretoria: Department of Corrections, 2005, www.dcs.gov.za/wp-content/uploads/2016/08/WHITEPAPER-8.pdf (accessed 11 August 2015)

18 JN Clark, Youth violence in South Africa: the case for a restorative justice response, Contemporary Justice Review, 15:1, 2012, https://doi.org/10.1080/10282580.2011. 653521.

19 Muntingh, An analytical study of South African prison reform after 1994, iii; GJ Super, Punishment, violence and grassroots democracy in South Africa: The politics of populist punitiveness, Punishment and Society, 18:3, 2016, https://doi.org/10.1177/1462474516645685.

20 Singh, Doing time for crime.

21 Clark, Youth violence in South Africa; Singh and Singh, A review of legislation pertaining to children.

22 C Badenhorst, Second year of the Child Justice Act's implementation: Dwindling numbers, Belville, Cape Town: Open Society Foundation for South Africa and The Child Justice Alliance, 2012, www.childjustice.org.za/publications/ BadenhorstCJAlmplementation2_2012.pdf (accessed 21 May 2019).

23 Singh and Singh, A review of legislation pertaining to children; A Van der Merwe and A Dawes, Toward good practice for diversion: The development of minimum standards in the South African child justice system, Journal of Offender Rehabilitation, 48:7, 2009, https://doi. org/10.1080/10509670903195993.
24 Z Hansungule, Questionable correction: Independent oversight of child and youth care centres in South Africa, APCOF Research Paper 19, 2018, http://apcof.org/wpcontent/uploads/no-19-child-and-youth-care-center-by-zitahansungule-.pdf (accessed 20 June 2019); Singh and Singh, A review of legislation pertaining to children.

25 Singh, Doing time for crime.

26 L Walgrave, Has restorative justice appropriately responded to retribution theory and impulses? in $\mathrm{H}$ Zehr and B Toews (eds), Critical Issues in Restorative Justice, New York: Criminal Justice Press and Devon: Willan Publishing, 2004, 4.

27 A Winton, Analysing the geographies of the 'transnational' gangs of Central America: The changing spaces of violence, Investigaciones Geográficas (Mx), 79, 2012; JM Cruz, Central American maras: From youth street gangs to transnational protection rackets, Global Crime, 11:4, 2010, https://doi.org/10.1080/17440572.2010.519518.

28 R Reguillo, cited in Winton Analysing the geographies of the 'transnational' gangs of Central America, 146.

29 United Nations Office on Drugs and Crime, Handbook of basic principles and promising practices on alternatives to imprisonment, Vienna: United Nations Office on Drugs and Crime, 2007.

30 J Garbarino, Lost boys: Why our sons turn violent and how we can save them, New York: Anchor Books, 1999.

31 Clark, Youth violence in South Africa.

32 GM Diamond, JD Lipsitz and Y Hoffman, Nonpathological response to ongoing traumatic stress, Peace and Conflict: Journal of Peace Psychology, 19:2, 2013, http://dx.doi. org/10.1037/a0032486.

33 Ibid; CB Roach, Shallow affect, no remorse: The shadow of trauma in the inner city, Peace and Conflict: Journal of Peace Psychology, 19:2, 2013, http://dx.doi.org/10.1037/ a0032530; G Stevens, G Eagle, D Kaminer et al., Continuous traumatic stress: Conceptual conversations in contexts of global conflict, violence and trauma, Peace and Conflict: Journal of Peace Psychology, 19:2, 2013, http://dx.doi. org/10.1037/a0032484.

34 Diamond, Lipsitz and Hoffman, Nonpathological response to ongoing traumatic stress; Roach, Shallow affect no remorse.

35 We take the position that even though agency may be limited by structural factors, individuals still make strategic choices that may even be a form of opposition to that which dominates (even if that may be further limiting, such as incarceration). See C Daiute, Human development and political violence, New York: Cambridge University Press, 2010.

36 K Mitton, Public health and violence, Critical Public Health, 29:2, 2019.

37 Dr Arlene Benjamin, Director of Restore Reconnect Rebuild (Pty) Ltd and founder of CASE (Community Action Towards a Safer Environment), personal communication, 9 October 2018.

38 P Burton, CL Ward, L Artz et al., Research bulletin: The Optimus study of child abuse, violence and neglect in South Africa, Cape Town: University of Cape Town and The Centre for Justice and Crime Prevention, 2015; D Kaminer, B du Plessis, A Hardy et al., Exposure to violence across multiple sites among young South African adolescents, Peace and 
Conflict: Journal of Peace Psychology 19:2, 2013, http:// dx.doi.org/10.1037/a0032487; D Kaminer, G Eagle and S Crawford-Browne, Continuous traumatic stress as a mental and physical health challenge: Case studies from South Africa, Journal of Health Psychology, 23:8, 2018, https:// doi.org/10.1177/1359105316642831; A Van der Merwe, A Dawes and CL Ward, The development of youth violence: an ecological understanding, in CL Ward, A Van der Merwe and A Dawes (eds), Youth violence: Sources and solutions in South Africa, Cape Town: UCT Press, 2013.

39 BD Perry, G Griffin, G Davis et al., The impact of neglect, trauma and maltreatment on neurodevelopment: Implications for juvenile justice practice, programs and policy, in AR Beech, AJ Carter, RE Mann et al. (eds), The Wiley Blackwell handbook of forensic neuroscience, $1^{\text {st }}$ ed, Hoboken; John Wiley and Sons Ltd, 2018. (Kindle version)

40 Ibid.

41 Ibid; G Griffin, EJ Germain and RG Wilkerson, Using a trauma-informed approach in juvenile justice institutions, Journal of Child \& Adolescent Trauma, 5, 2012, https://doi.or g/10.1080/19361521.2012.697100.

42 Ibid; J Garbarino, Listening to killers: lessons learned from my twenty years as a psychological expert witness in murder cases, Berkeley: University of California Press, 2015.

43 Garbarino, Lost Boys; EA Fattah, Victimology's debt to Nils Christie: The outlasting legacy of a free thinker, Tamida, 19:2, 2012; J Gilligan, Punishment and violence: Is the criminal law based on one huge mistake, Social Research, 67:3, 2000, https://www.jstor.org/stable/40971409.

44 Perry et al., The impact of neglect, trauma and maltreatment on neurodevelopment.

45 G Griffin et al, Using a trauma-Informed approach in juvenile justice institutions.

46 Stevens et al., Continuous traumatic stress.

47 G Johnstone and DW Van Ness, The meaning of restorative justice, in G Johnstone and DW Van Ness (eds), Handbook of restorative justice, Devon: Willan Publishing, 2007; S Sharpe, How large should the restorative justice 'tent' be? in $\mathrm{H}$ Zehr and B Toews (eds), Critical Issues in Restorative Justice, New York: Criminal Justice Press and Devon: Willan Publishing, 2004

48 D Van Ness, An overview of restorative justice around the world, Paper presented at Eleventh United Nations Congress on Crime Prevention and Criminal Justice, Bangkok, Thailand, 18-25 April 2005, 3, https://assets.justice.vic. gov.au/njc/resources/c4518c8a-c200-4623-afd1-42e25 5b62cf9/01\%2Ban\%2Boverview\%2Bof\%2Brestorative\% 2Bjustice.pdf (accessed 12 September 2018); The Child Justice Act 2008 (Act 75 of 2008) defines restorative justice 'as an approach to justice that aims to involve the child offender, the victim, the families concerned and community members to collectively identify and address harms, needs and obligations through accepting responsibility, making restitution, taking measures to prevent a recurrence of the incident and promoting reconciliation'.

49 Van Ness, An overview of restorative justice around the world; Pranis, Restorative values, in Johnstone and Van Ness (eds), Handbook of restorative justice.

$50 \mathrm{H}$ Zehr and $\mathrm{H}$ Mika, Fundamental concepts in restorative justice, Contemporary Justice Review, 1, 1998.
$51 \mathrm{H}$ Zehr and A Gomar, The little book of restorative justice, Intercourse, PA: Good Books, 2003, www.unicef.org/tdad/ littlebookrjpakaf.pdf (accessed 10 September 2018).

52 EA Fattah, Is punishment the appropriate response to gross human rights violations? Is a non-punitive justice system feasible? Acta Juridica, 2007, https://hdl.handle.net/10520/ EJC52689.

53 O Vidoni Guidoni, The ambivalences of restorative justice: Some reflections on an Italian prison project, Contemporary Justice Review, 6:1, 2003, https://doi.org/10.1080/1028258 032000055658.

54 These are informed by Griffin et al., Using a trauma-informed approach in juvenile justice institutions, and A Benjamin, More than a drop in the ocean: Breaking the cycle of violence, Cape Town: CASE Publications, 2011.

55 Griffin et al., Using a trauma-informed approach in juvenile justice institutions.

56 Ibid; Perry et al., The impact of neglect, trauma and maltreatment on neurodevelopment.

57 Perry et al., The impact of neglect, trauma and maltreatment on neurodevelopment; Garbarino, Listening to killers; Gilligan, Punishment and violence.

58 Griffin et al., Using a trauma-informed approach in juvenile justice institutions.

59 Perry et al., The impact of neglect, trauma and maltreatment on neurodevelopment, Box 31.1.

60 Griffin et al., Using a trauma-informed approach in juvenile justice institutions; DJ Siegel, Mindsight: The new science of personal transformation, New York: Bantam Books, 2010.

61 Super, Punishment, violence and grassroots democracy in South Africa.

62 Community Connections for Youth, Building community capacity to serve youth in the justice system, South Bronx, NY: Alternatives to Incarceration Training Institute, 2015, introductory page.

63 C Shearing and J Cartwright, Popular policing video lecture: Part II, UCT Open Content, 2010, http://opencontent.uct. ac.za/Law/Popular-Policing-Video-Lecture-Part-II (accessed 10 January 2012).

64 Griffin et al., Using a trauma-informed approach in juvenile justice institutions.

65 Garbarino, Lost Boys, 233.

66 B Toews and D Van Buren, Designing justice and designing spaces toolkit, 2015, www.designingjustice.com/toolkit/ (accessed 01 June 2015).

67 S Sathian, Deanna van Buren is making space for a new kind of justice, Ozy.com, 26 August 2015, www.ozy.com/risingstars/deanna-van-buren-is-making-space-for-a-new-kind-ofjustice/40562 (accessed 28 August 2015). 